\title{
A nursery ground for four tropical Penaeus species: Laguna Joyuda, Puerto Rico
}

\author{
Allan W. Stoner \\ Center for Energy and Environment Research, University of Puerto Rico, Mayaguez, Puerto Rico 00708, USA
}

\begin{abstract}
A 1 yr survey of shrimps in Laguna Joyuda, Puerto Rico, yielded 4 Penaeus spp.: P. notialis (47\% of identified Penaeus spp.), P. subtilis (45\%), P. brasiliensis ( $7 \%$ ), and P. schmitti (1\%). Many of the shrimps collected were small juveniles ( 3 to $8 \mathrm{~mm} \mathrm{CL}$ ), but only 10 postlarvae were collected inside the lagoon. Recruitment occurred year-round, but highest numbers of $P$. subtilis were collected in the dry season and total catch was positively correlated with salinity. Two maxima in abundance were observed for $P$. notialis, with evidence for large annual variation in recruitment and stock size. Spatial variation in the total number of shrimp collected appeared to be related to sediment types or food availability. $P$. subtilis was associated with the more muddy stations, but there was broad overlap in the abundance of the 4 species, and only weak indication of partitioning in space and time.
\end{abstract}

\section{INTRODUCTION}

Many crustaceans are sought in world fisheries, but the most important are the tropical and subtropical shrimps belonging to the family Penaeidae. There is a vast literature on the penaeids of North America, and a rapidly growing knowledge of Australian species (see reviews in Garcia \& Le Reste 1981, Gulland \& Rothschild 1984). All of the Penaeus spp., which make up the bulk of the fisheries, are believed to have similar life histories, with demersal eggs spawned in offshore waters on island and continental shelves. Penaeid postlarvae arrive in nearshore inlets and estuaries at about 6 to $12 \mathrm{~mm}$ in length (Baxter 1962, Tabb et al. 1962, Khandker 1969) and are adapted to using flood tides to move into estuarine habitats (Copeland \& Truitt 1965, Duronslet et al. 1972, Young \& Carpenter 1977, Staples 1980). The well-established importance of estuarine habitats as nurseries for Penaeus spp. (Kutkuhn 1966, Parker 1970, Edwards 1978) is believed to be related to high survivorship of juvenile shrimps promoted by abundance of protective cover and high concentrations of food in brackish water habitats (Hoese 1960, Barrett \& Gillespie 1973, Zimmerman et al. 1984). After 2 to 4 mo of growth in the estuarine nurseries, subadult penaeids emigrate to offshore shelf areas to spawn.

There are 4 Penaeus spp. in the Caribbean region: $P$. brasiliensis, $P$. notialis, $P$. schmitti, and $P$. subtilis. Although all of these species are major contributors to the world shrimp catch (Ewald 1969, Neiva 1969, Nikolic \& Ruiz 1969, Lindner 1971), very little is known about the biology and ecology of these and other tropical Penaeus spp. Exploratory sampling of commercial shrimps in Puerto Rico (Stoner unpubl) suggested that the shrimps are abundant where there are major estuarine and wetland habitats. Laguna Joyuda is an ideal habitat in which to study shrimp population dynamics and productivity because of its single narrow inlet, and because shrimp are abundant and unfished in the lagoon basin.

Here, I describe the nursery use of a highly-productive lagoon in Puerto Rico by 4 sympatric Penaeus spp., their immigration patterns, seasonal cycles, and distributional patterns within the lagoon. This study is part of a continuing, long-term, multidisciplinary analysis of the Laguna Joyuda ecosystem in which Penaeus species play an important role.

\section{METHODS AND MATERIALS}

Laguna Joyuda (Fig. 1) is a shallow, brackish-water basin on the west coast of Puerto Rico $\left(18^{\circ} 07^{\prime} \mathrm{N}\right.$, $67^{\circ} 11^{\prime} \mathrm{W}$ ). Total surface area of the lagoon is $1.21 \mathrm{~km}^{2}$ in a total drainage area of $5.95 \mathrm{~km}^{2}$ (Carvajal-Zamora et al. 1980). Average depth is $1.5 \mathrm{~m}$. One narrow channel $0.5 \mathrm{~km}$ long and averaging $0.5 \mathrm{~m}$ deep represents the only connection to the Puerto Rico shelf. Tidal 


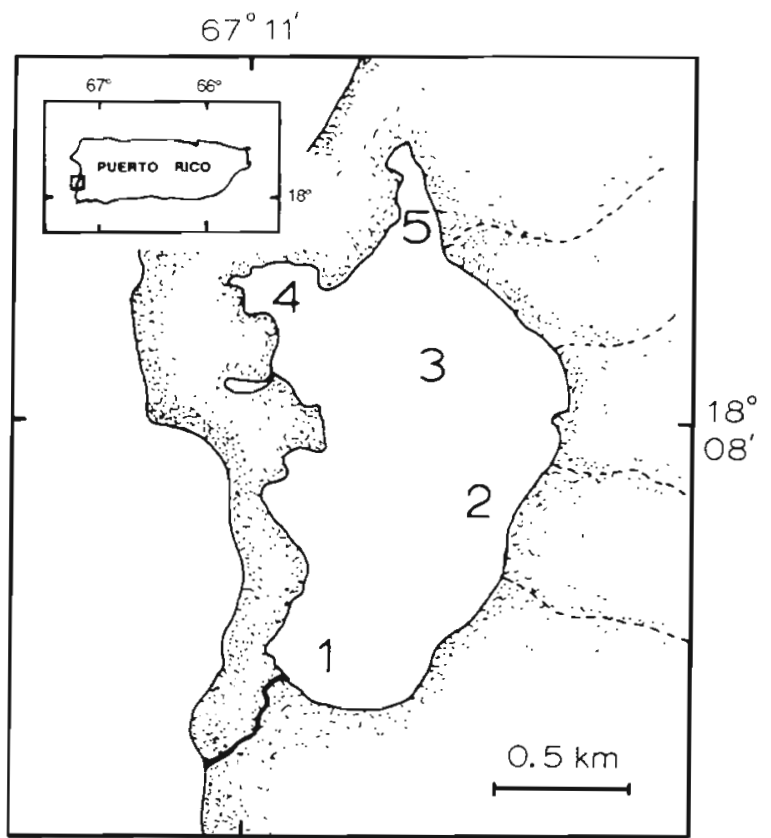

Fig. 1. The Laguna Joyuda system in western Puerto Rico showing the shrimp collection sites

range inside the lagoon is $15 \mathrm{~cm}$ and turnover time is long.

Lagoon sediments are mostly fine muds and shell fragments with very high organic content derived from red, white, and black mangroves which fringe $75 \%$ of the shoreline. Small patches of the seagrasses Thalassia testudinum and Ruppia maritima exist in the lagoon, but most of the bottom is unvegetated. The lagoon is polyhaline with a long-term salinity range of 4 to $44 \mathrm{ppt}$, depending upon precipitation and degree of channel closure (Stoner \& Lopez 1985). Except during high rainfall events, there is little vertical or longitudinal variation in water column temperature or salinity.

Human activity in the drainage basin is slight, consisting mostly of small private residences and pasture for cattle on the rolling, grass-covered hillside. Despite its small size, the lagoon supports a relatively productive fishery, primarily in the form of gill-netting for a variety of fishes. Shrimps are fished only in the lagoon's channel with simple weirs and cast nets at night; therefore, shrimp populations in the basin are free from fishing mortality.

For the present study, shrimp collections were made at 5 stations in Laguna Joyuda between August 1984 and August 1985 (Fig. 1). The stations represent the major bottom types in the lagoon as well as various distances from the inlet. Station characteristics are summarized in Table 1. Water quality measures were made at each station and date of biological collections. Surface and bottom waters, collected with a Kemmerer bottle, were measured for temperature and for salinity with a refractometer. Dissolved oxygen was measured at the surface and near the bottom with an air-calibrated oxygen probe (Yellow Springs Instruments). Depth was measured with a lead line marked in $10 \mathrm{~cm}$ intervals.

Sediments were collected at the 5 stations using a coring device of $8 \mathrm{~cm}$ diameter. A subsample of the upper $5 \mathrm{~cm}$ of freshly collected individual cores was dried to constant mass at $80^{\circ} \mathrm{C}$, then incinerated at $550^{\circ} \mathrm{C}$ for $4 \mathrm{~h}$ to determine organic content. After washing to remove salts and to extract the silt-clay fraction, another sediment subsample of approximately $50 \mathrm{~g}$ was analysed for granulometric properties using standard Ro-Tap procedures. Silt-clay fractions were analysed using standard pipet procedures (Folk 1966). Product moment statistics were generated for mean

Table 1 Summary of physical and sedimentological characteristics at 5 stations in Laguna Joyuda, Puerto Rico, 1984-85. Values are mean \pm standard deviation. Reference to detritus indicates macroscopic particles retained on a $0.5 \mathrm{~mm}$ mesh screen

\begin{tabular}{|c|c|c|c|c|c|c|}
\hline \multirow[t]{2}{*}{ Station } & \multirow{2}{*}{$\begin{array}{l}\text { Salinity } \\
\qquad(\%) \\
n=17\end{array}$} & \multirow{2}{*}{$\begin{array}{l}\text { Dissolved } \\
\text { oxygen (mgl i) } \\
n=11\end{array}$} & \multirow{2}{*}{$\begin{array}{l}\text { Depth } \\
(m) \\
n=17\end{array}$} & \multicolumn{2}{|c|}{ Sediments } & \multirow{2}{*}{ Description } \\
\hline & & & & $\begin{array}{l}\text { Organics" } \\
(\% \text { of dry wt })\end{array}$ & $\begin{array}{c}\text { Mean grain } \\
\text { diameter }(\varnothing) n=2\end{array}$ & \\
\hline 1 & $24 \pm 5$ & $6.5 \pm 0.9$ & $1.2 \pm 0.1$ & $13.1 \pm 5.6$ & $0.99 \pm 0.18$ & $\begin{array}{l}\text { Shelly mud, high de- } \\
\text { tritus }\end{array}$ \\
\hline 2 & $24 \pm 6$ & $6.7 \pm 1.0$ & $1.4 \pm 0.2$ & $13.8 \pm 2.7$ & $1.20 \pm 0.27$ & $\begin{array}{l}\text { Medium sand, low de- } \\
\text { tritus }\end{array}$ \\
\hline 3 & $24 \pm 6$ & $6.8 \pm 0.9$ & $1.7 \pm 0.3$ & $21.4 \pm 6.5$ & $1.69 \pm 0.22$ & $\begin{array}{l}\text { Shelly mud, high de- } \\
\text { tritus }\end{array}$ \\
\hline 4 & $23 \pm 8$ & $6.1 \pm 0.9$ & $1.6 \pm 0.3$ & $16.2 \pm 5.2$ & $1.38 \pm 0.35$ & $\begin{array}{l}\text { Shelly mud, moderate } \\
\text { detritus }\end{array}$ \\
\hline 5 & $25 \pm 5$ & $5.8 \pm 1.2$ & $1.5 \pm 0.2$ & $17.6 \pm 1.3$ & $4.23 \pm 0.63$ & $\begin{array}{l}\text { Coarse mud, low de- } \\
\text { tritus }\end{array}$ \\
\hline
\end{tabular}


grain size. In most cases, organic content was determined at least monthly, while grain size determinations were made once in the wet season and once in the dry season.

Shrimps were collected with a $5 \mathrm{~m}$ semi-balloon, otter trawl with $2.5 \mathrm{~cm}$ mesh wings and body and a $5 \mathrm{~mm}$ cod-end liner. The inefficiency of estimating shrimp standing stocks with trawl gear is recognized (Zimmerman et al. 1984); however, the otter trawl represents the most practical gear for collecting large numbers of shrimp with replication where water depth and very soft sediments preclude other methods. Replicate trawls were made at each station, towing the net with a small skiff at $2.5 \mathrm{kn}$ a standard distance of $70 \mathrm{~m}$.

Preliminary collections were made in the lagoon to determine the optimal time of day for sampling. Four sets of daytime trawl collections made in August and September 1984 yielded no shrimp, while shrimp were abundant in night collections. More systematic sampling of shrimps through $24 \mathrm{~h}$ periods in February and August 1987 showed insignificant variation in catch per unit effort of Penaeus notialis, $P$. subtilis, and $P$. brasiliensis throughout the darkness hours, regardless of tidal state or date (Stoner unpubl.). Low numbers of $P$. schmitti precluded making any conclusions about its catchability patterns. Night collections yielded nearly 6 times as many shrimp per unit effort as daytime collections; consequently, all collections for the survey were made at least $1 \mathrm{~h}$ after sunset.

Because of known movement of shrimps to and from the lagoon on a lunar periodicity (Stoner 1985), trawl collections were made to determine the optimal time of collection during any one lunar month. Between 20 Aug and 20 Sep 1984, 10 replicate trawl collections were made during darkness hours at weekly intervals on each of the 4 moon phases at Stns 1 and 4 . The results indicated that 6 replicates would be sufficient to reach a stable mean number of shrimp captured, as well as an asymptotic number of fish and shrimp species per unit effort. Highest numbers of shrimp were collected during the last quarter of the moon; consequently, all subsequent trawl collections were made at night on the last quarter of the moon, using 6 replicate hauls at each of the 5 stations.

Shrimps were preserved in $10 \%$ formaldehyde diluted with lagoon water and returned to the laboratory for examination. All shrimps were identified to species when possible, sex was determined, and each was measured for carapace length (CL). The identification of juvenile Penaeus to species is difficult and timeconsuming. Generally, specimens smaller than 6 to $8 \mathrm{~mm}$ CL were classified as Penaeus juveniles because of the very close taxonomic relationships of the species and because of the lack of distinct species characteristics (all collected were of the grooved variety, i.e.
Penaeus notialis, $P$. subtilis, and $P$. brasiliensis). Juveniles larger than $8 \mathrm{~mm}$ were identified according to the characters outlined by Perez-Farfante (1970).

To evaluate spatial and temporal variation for the dominant shrimp species 3-way ANOVA procedures were applied to abundance data (Sokal \& Rohlf 1969). When Bartlett's test indicated heterogeneity of group variances, $\log _{10}$ transformations of the count data were made.

In addition to the otter trawl collections, a $1.6 \mathrm{~m}$ beam trawl with $1.0 \mathrm{~mm}$ mesh to the design of Renfro (1963) was deployed each month to collect shrimp postlarvae. The small trawl was towed $50 \mathrm{~m}$ between 2 floats at each station before the otter trawl was deployed. The year-long survey yielded only 10 Penaeus postlarvae, distributed over all of the 5 stations, and no further analysis will be reported here.

\section{RESULTS}

\section{Station characteristics}

There were no significant differences in salinity or temperature among the stations (ANOVA, $\mathrm{p}>0.05$ ). Salinity ranged from 14 to 30 ppt during the study period, with mean salinity values between 23 and $24 \mathrm{ppt}$ at all stations. Lagoon salinity was lowest (14 to $15 \mathrm{ppt}$ ) between September and November and was highest in August of both 1984 and 1985 (Fig. 2). Water

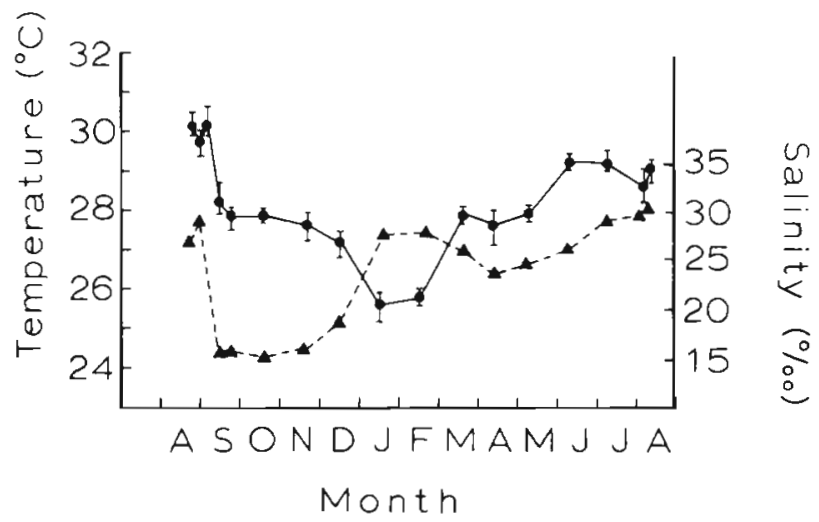

Fig. 2. Bottom water temperature and salinity in the Laguna Joyuda, 1984-1985. Temperatures (•) shown are means and ranges of temperatures observed at the 5 collection sites. Salinity values (4) showed little spatial variation throughout the sampling period

temperature was lowest in January and February (25 to $26^{\circ} \mathrm{C}$ ) and highest in August and September (29 to $31^{\circ} \mathrm{C}$ ) (Fig. 2). Although dissolved oxygen levels in the lagoon were normally close to saturation, absolute oxygen concentrations were lower at Stns 4 and 5 than at 
Stns 1, 2, and 3 (ANOVA and Duncan's multiple range, test, $\mathrm{p}<0.005$ ). Water depth was significantly less at Stn $1($ mean $=1.2 \mathrm{~m})$ than at the other stations $(1.4$ to $1.7 \mathrm{~m}$ ) (ANOVA, $\mathrm{p}<0.05$ ); however, all of the stations had some slope in the bottom over which trawls were made and it is unlikely that the depth of Stn 1 was a major factor determining the differences in shrimp fauna found there.

Sediment characteristics constituted the greatest physical variation in the sampling stations (Table 1). Sediment organic content differed significantly among stations (ANOVA, $p<0.05$ ) with highest levels at $\operatorname{Stn} 3$ $(21 \%)$ and approximately equal and lowest organic content at Stns 1 and 2 (13 to $14 \%$ ). Sediments at Stns 4 and 5 were intermediate in organic content, but pairwise statistical comparisons were not made because of large differences in number of samples.

\section{Shrimp populations}

Four Penaeus spp. were collected in Laguna Joyuda, of which $P$. notialis and $P$. subtilis together comprised over $92 \%$ of the identified specimens in approximately equal numbers (Table 2). P. brasiliensis accounted for

Table 2. Penaeus spp. Total numbers collected in Laguna Joyuda, 1984-85

\begin{tabular}{|c|c|c|c|}
\hline Species & Sex & $\begin{array}{c}\text { Total } \\
\text { collected }\end{array}$ & $\begin{array}{c}\text { Percent } \\
\delta \text { or } 9\end{array}$ \\
\hline \multirow[t]{2}{*}{ Penaeus notialis } & $\begin{array}{l}8 \\
0\end{array}$ & $\begin{array}{l}336 \\
363\end{array}$ & $\begin{array}{l}48.1 \\
51.9\end{array}$ \\
\hline & Total & 699 & 100.0 \\
\hline \multirow[t]{2}{*}{ Penaeus subtilis } & $\begin{array}{l}0 \\
2\end{array}$ & $\begin{array}{l}299 \\
367\end{array}$ & $\begin{array}{l}44.9 \\
55.1\end{array}$ \\
\hline & Total & 666 & 100.0 \\
\hline \multirow[t]{2}{*}{ Penaeus brasiliensis } & $\begin{array}{l}d \\
q\end{array}$ & $\begin{array}{l}69 \\
34\end{array}$ & $\begin{array}{l}67.0 \\
33.0\end{array}$ \\
\hline & Total & 103 & 100.0 \\
\hline \multirow[t]{2}{*}{ Penaeus schmitti } & $\begin{array}{l}\partial \\
9\end{array}$ & $\begin{array}{l}8 \\
6\end{array}$ & $\begin{array}{l}57.1 \\
42.9\end{array}$ \\
\hline & Total & 14 & 100.0 \\
\hline Penaeus juveniles & $\begin{array}{c}\delta \\
\oint \\
\text { Undet. } \\
\text { Total }\end{array}$ & $\begin{array}{r}472 \\
420 \\
53 \\
945\end{array}$ & $\begin{array}{r}50.0 \\
44.0 \\
5.6 \\
100.0\end{array}$ \\
\hline
\end{tabular}

$7.0 \%$ of the total collection, and $P$. schmitti accounted for only $0.9 \%$ of the collection. Unidentified juveniles, mostly 3 to $8 \mathrm{~mm} \mathrm{CL}$, made up $39 \%$ of the total collection.

Sex ratios were not significantly different from $1: 1$ in 3 of the 5 categories: Penaeus notialis $\left(\chi^{2}=1.04\right.$, $\mathrm{p}>0.1), P . \operatorname{schmitti}\left(\chi^{2}=0.29, \mathrm{p}>0.1\right)$, or Penaeus juveniles $\left(x^{2}=3.03, p>0.05\right)$. Females were significantly more abundant than males in $P$. subtilis $\left(\chi^{2}=\right.$ $6.94, \mathrm{p}<0.01)$, but less abundant in $P$. brasiliensis $\left(\chi^{2}=\right.$ $11.89, \mathrm{p}<0.005)$. When sex ratio patterns were examined at individual stations for $P$. notialis and $P$. subtilis, results were the same as those found over all stations except that $P$. subtilis showed no significant variation from a $1: 1$ sex ratio at Stns 2 and $4(\mathrm{p}>0.05)$. Other species were captured in too few numbers to examine differences at individual stations.

Three-way ANOVA of shrimp abundance data between stations, dates, and the 3 most abundant species showed significant interaction effects (p $<0.001)$ for all combinations of factors using log-transformed data (Table 3). Because Penaeus brasiliensis

Table 3. Results of 3-way analysis of variance of the number of shrimp collected per trawl sample. Data were log-transformed

\begin{tabular}{|c|c|c|c|c|}
\hline Source & df & MS & $F$ & $\mathrm{p}$ \\
\hline Species & 2 & 46.871 & 233.82 & $<0.001$ \\
\hline Station & 4 & 10.542 & 51.591 & $<0.001$ \\
\hline Date & 11 & 2.770 & 13.817 & $<0.001$ \\
\hline Species $\times$ Station & 8 & 2.964 & 14.785 & $<0.001$ \\
\hline Species $\times$ Date & 22 & 1.902 & 9.488 & $<0.001$ \\
\hline Station $\times$ Date & 44 & 0.613 & 3.059 & $<0.001$ \\
\hline Species $\times$ Station $\times$ Date & 88 & 0.380 & 1.898 & $<0.001$ \\
\hline Error & 900 & 0.200 & & \\
\hline
\end{tabular}

abundances were low throughout the area, the 3-way ANOVA was also run including only $P$. notialis and $P$. subtilis; all interaction terms were significant as in the 3-species model.

The observed spatial differences in the Penaeus community are related to differences in the relative abundance of the most abundant species (Table 4). Stations in the northern arms of the lagoon (Stns 4 and 5) were characterized by low relative abundance of $P$. notialis ( 25 to $27 \%$ of total numbers) and high relative abundances of $P$. subtilis (63 to $69 \%$ ). More open areas of the lagoon (Stns 1, 2, and 3) had higher relative abundances of $P$. notialis ( 47 to $57 \%$ ). Eleven of the $14 P$. schmitti were collected at Stn 5 .

One-way ANOVA with log-transformed data $(F=$ 79.49, $\mathrm{p}<0.001)$ also indicated significant station effects on the total number of shrimps captured. Stn 1 yielded significantly higher numbers of shrimp than all other stations ( $\mathrm{p}<0.005$ ), while Stns 2,3 , and 4 yielded similar catches, and Stn 5 yielded lower numbers than any other station (Duncan's multiple range test; $\mathrm{p}<$ $0.005)$.

The seasonal abundance patterns for total shrimp collected were most pronounced near the lagoon's inlet 
Table 4. Penaeus spp. Comparison of shrimp communities at 5 stations in Laguna Joyuda, 1984-85. Numbers for individual species are total numbers collected and (in parentheses) percent of total catch, excluding juveniles; 72 trawl samples were taken at each station

\begin{tabular}{|c|c|c|c|c|c|}
\hline \multirow[t]{2}{*}{ Species } & \multicolumn{5}{|c|}{ Station } \\
\hline & 1 & 2 & 3 & 4 & 5 \\
\hline Penaeus notialis & $280(57.5)$ & $129(54.2)$ & $125(47.0)$ & $66(26.5)$ & $34(25.2)$ \\
\hline Penaeus subtilis & $162(33.3)$ & $105(44.1)$ & $120(45.1)$ & $172(68.5)$ & $85(63.0)$ \\
\hline Penaeus brasiliensis & $43(8.8)$ & $4(1.7)$ & $21(7.9)$ & $12(4.8)$ & $5(3.7)$ \\
\hline Penaeus schmiti & $2(0.4)$ & - & - & $1(0.4)$ & $11(8.1)$ \\
\hline Penaeus juveniles & $499(50.6)$ & $65(21.4)$ & $171(39.1)$ & $121(32.5)$ & $58(30.1)$ \\
\hline Total no. & 986 & 303 & 437 & 372 & 193 \\
\hline
\end{tabular}

(Stn 1) with little concordance among stations (Fig. 3). This concurs with the significant station-month interaction term in the 3-way ANOVA. Mean numbers of individuals collected per trawl varied by a factor of

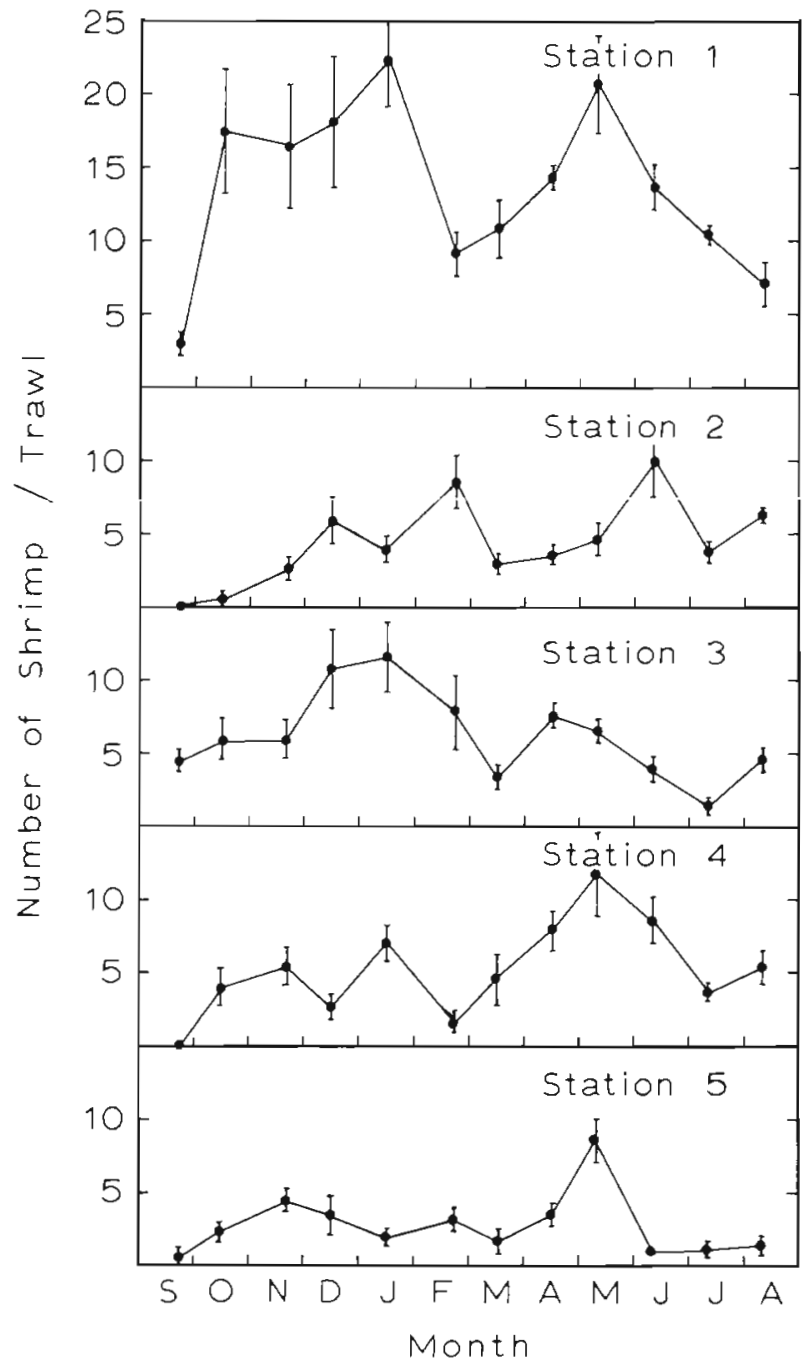

Fig. 3. Penaeus spp. Total number collected at the 5 sampling stations, 1984-1985. Each point represents the mean catch per trawl $(n=6)+1 \mathrm{SE}$ about 10 over different months at Stn 1 and exhibited a bimodal pattern with a broad peak occurring between October and January, and a narrow peak in May through June. Catch variation demonstrated less amplitude at Stns 2 and 3 than at Stn 1, but bimodal patterns of shrimp abundance occurred at these stations. At Strns 4 and 5, there were weak maxima in shrimp yields between October and January, with strongest peaks in May.

Relative species abundances also differed over time as indicated by the significant species-month interaction term. Penaeus notialis showed strong maxima in November through January and April through the end of the sampling period, while $P$. subtilis was most abundant in February through May (Fig. 4). Different shrimp assemblages at the 5 stations coupled with different seasonal abundance patterns in individual species, particularly $P$. notialis and $P$. subtilis, explains the station-month interaction term in the ANOVA.

Despite evidence for at least weak seasonality in the primary Penaeus spp., regression analysis showed little correlation between shrimp abundance in the lagoon and either water temperature or salinity (simple linear and log-transformed data). No significant correlations $(p>0.005)$ were found between these environmental factors and total shrimp catch, or catches of Penaeus juveniles, $P$. notialis, and $P$. brasiliensis. Abundance of $P$. subtilis, however, was positively correlated with salinity in the lagoon $(F=5.42, p<0.05 ; r=0.593)$ and appeared to be associated with the wet season.

It is clear from the number of very small unidentified Penaeus spp. (Fig. 4) and length-frequency data for $P$. notialis (Fig. 5) and P. subtilis (Fig. 6) that juveniles dominate the shrimp community year round in Laguna Joyuda. Despite year-round recruitment by shrimp to the lagoon, and great temporal overlap between $P$. notialis and $P$. subtilis, there were differences in times of peak recruitment by the 2 primary species. High abundance of $P$. notialis less than $10 \mathrm{~mm} \mathrm{CL} \mathrm{in}$ October (Fig. 5) suggests that the first major peak in unidentified Penaeus spp. (Fig. 4) was related to 


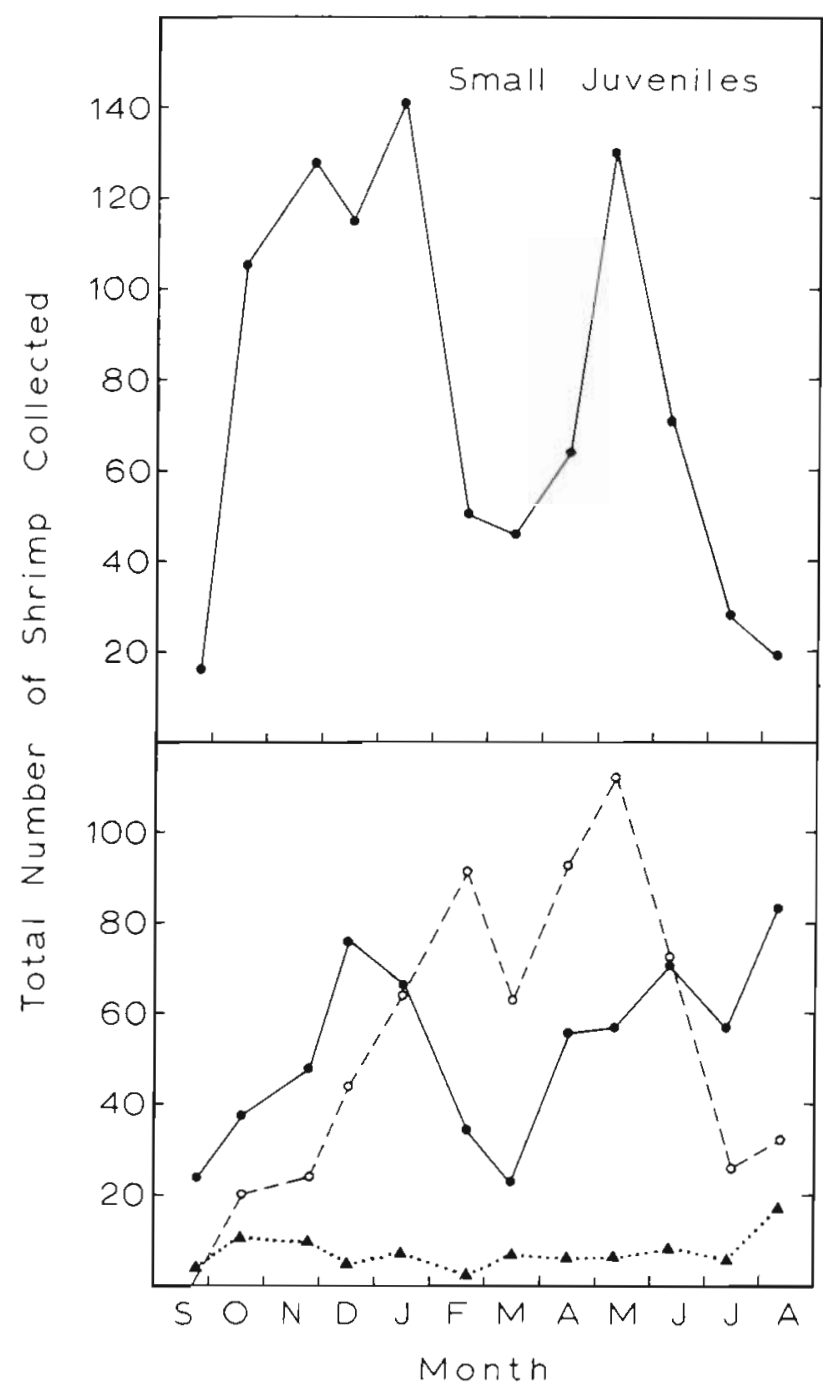

Fig. 4. Penaeus spp. Total number of shrimps collected in Laguna Joyuda over all stations ( 30 trawls over 5 stations), 1984-1985. Top: unidentified Penaeus spp., mostly 3 to $8 \mathrm{~mm}$ CL. Bottom: identified species - $(\bullet)$ Penaeus notialis; $(0) P$. subtilis; (4) P. brasiliensis

recruitment by that species. $P$. notialis continued to dominate the lagoon until January. Largest abundance of $P$. subtilis smaller than $10 \mathrm{~mm}$ CL occurred in May and June (Fig. 6), corresponding with the second peak of unidentified juveniles and the maximum population size for the species. A second period of $P$. notialis abundance occurred between May and June 1985, however, and the second peak in juvenile abundance represents both of the 2 abundant species.

Differences in recruitment to the lagoon by the 2 primary species and differential distributions account for station-month interactions. Late spring/early summer abundance of shrimp at the northern stations was a result of recruitment primarily by Penaeus subtilis,

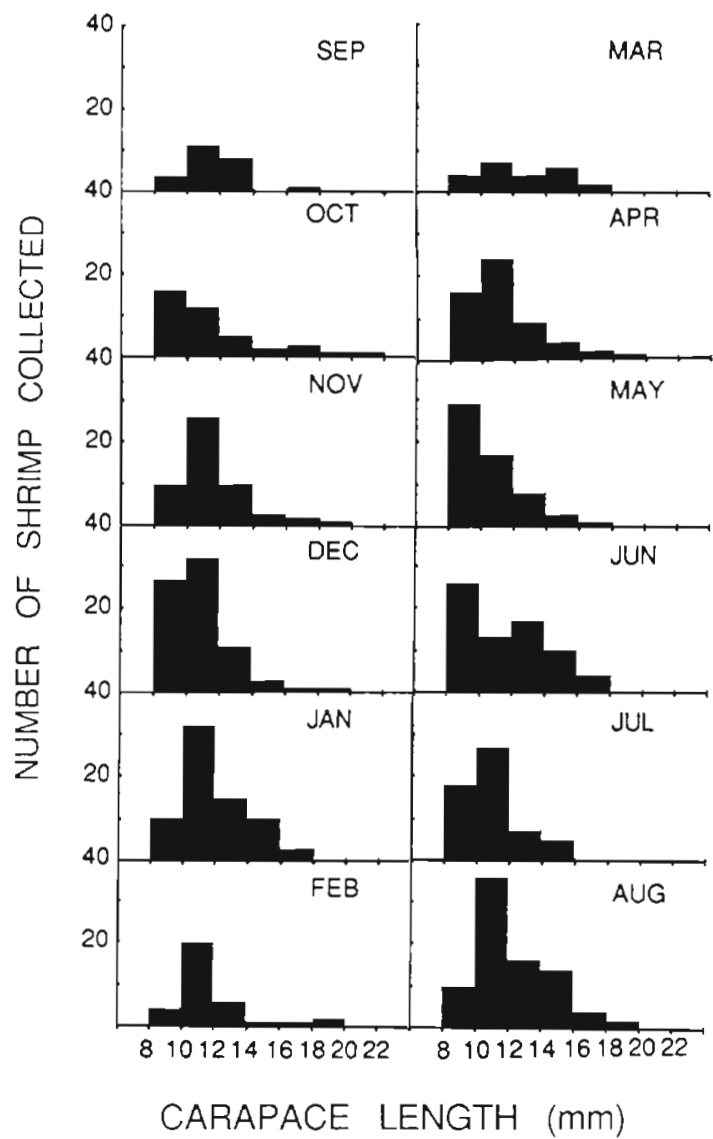

Fig. 5. Penaeus notialis. Length-frequency distribution of shrimps collected in Laguna Joyuda, 1984-1985, shown by month

while bimodal abundance patterns observed at Stns 1, 2 and 3 were a result of 2 abundant species.

\section{DISCUSSION}

The shrimp fauna of Laguna Joyuda included all 4 of the Penaeus spp. known from the Caribbean region. The relative abundances of the species, however, are variable with geographic location. In waters of the Yucatan and Central and South America, P. brasiliensis and $P$. schmitti are the 2 primary fishery species, while $P$. notialis is relatively unimportant (Lindner 1971 , Fischer 1978, Dragovich 1981). Unlike continental shrimp communities, $P$, notialis was the most abundant species in Laguna Joyuda, with $P$. subtilis second in abundance. Low number of $P$. brasiliensis in the lagoon is consistent with Fischer's (1978) conclusion that the species is relatively uncommon in Antilles waters

As is true for most Penaeus spp., the individuals collected in the estuarine habitat were all juveniles. Reproductively mature individuals, including $P$. notialis and $P$. subtilis females with spermatophores, 


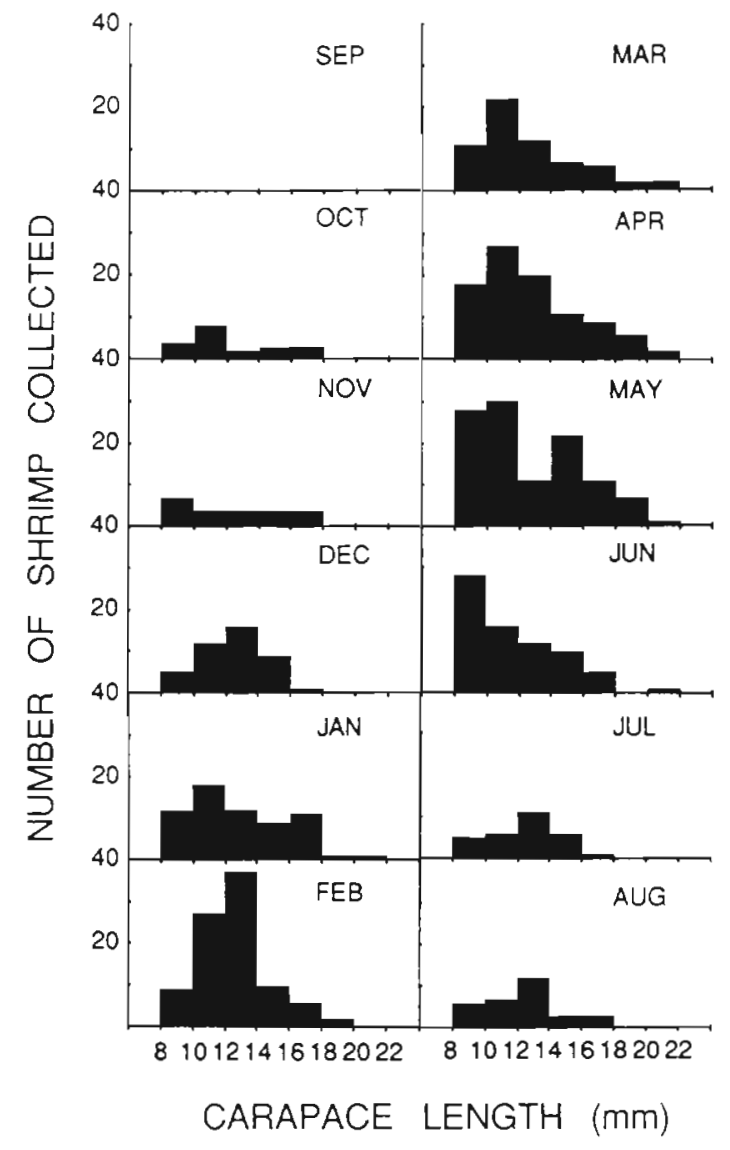

Fig. 6. Penaeus subtilis. Length-frequency distribution of shrimps collected in Laguna Joyuda, 1984-1985, shown by month

have been collected in trawl samples on the island shelf in high salinity areas (Stoner unpubl.). Many of these mature shrimp have been collected within $3 \mathrm{~km}$ from shore, and the entire life span of Penaeus spp. in Puerto Rico probably occurs within a narrow area. Juvenile Penaeus spp. have also been collected in high salinity embayments on the west coast of the island, and Penaeus spp. may not require estuarine habitats for successful growth and survival. The general lack of estuaries within the West Indies may have resulted in the evolution of less estuarine dependence among penaeids of this region.

Nonetheless, Penaeus spp. were very abundant in trawl collections from Laguna Joyuda, and the lagoon may produce as much as $955 \mathrm{~kg}$ wet weight of shrimp ha ${ }^{-1} \mathrm{yr}^{-1}$ (Stoner 1985). High abundance and productivity of shrimp within the lagoon may be related to high detrital inputs typical of tropical estuaries (Qasim \& Sankaranarayana 1972, Odum \& Heald 1975, Wells 1984). Levine (1981) determined that total litter fall into Laguna Joyuda was $1919 \mathrm{~g}$ dry wt $\mathrm{m}^{-2}$, a value higher than any other he found in the literature. A blue-green algal mat in the lagoon, however, provides the carbon for a wide variety of organisms and is probably the most important carbon source for Penaeus spp. (Stoner \& Zimmerman unpubl.).

High numbers of shrimp in the lagoon may also be related to low numbers of predators. A large variety of demersal fishes have been reported from the lagoon (Stoner 1986), but few of the total number appear to be shrimp predators. Of the total, only Bairdiella ronchus and relatively uncommon Lutjanus spp. frequently have Penaeus spp. in their stomachs. Large swimming crabs Callinectes spp. also consume Penaeus spp. (Stoner \& Buchanan unpubl.), but the crabs are not abundant in the lagoon (Buchanan \& Stoner 1988).

Spatial patterns in the abundance of shrimps in Laguna Joyuda suggest that abundance of foods may have a significant influence on the species collected. Gut analyses for Penaeus notialis and $P$. subtilis showed that capitellid polychaetes and amphipods constitute the most important food items for Joyuda shrimps (Stoner \& Zimmerman unpubl.). Shrimp were most abundant at Stns 1 and 3 where polychaete and amphipod standing stocks were highest (Stoner unpubl.); shrimp were fewest in number at $\operatorname{Stn} 5$, where foods were least abundant. Shrimp abundance patterns within the lagoon closely paralleled the patterns observed for demersal fishes (Stoner 1986) suggesting similar distributional mechanisms. The relationship between shrimp abundance patterns and macrobenthic food items is currently under investigation in Laguna Joyuda.

Differences in the distributional patterns among the Penaeus spp. within Laguna Joyuda may be related to specific sediment requirements. North American Penaeus spp. are known to select different habitats on the basis of sediment grain size and organic content (Williams 1955, Grady 1971, Rulifson 1981), and Fischer (1978) noted some differences in sediment associations among adult penaeids in the Caribbean. In Laguna Joyuda, the ratio of $P$. subtilis to $P$. notialis decreased with increasing mean grain size, and juvenile $P$. subtilis may prefer the finer muds.

Recruitment of small juvenile shrimp to Laguna Joyuda extended over a major portion of the year, but showed pronounced lows during August and September, and a possible relationship with seasonal rainfall patterns. Occurrence of the smallest Penaeus subtilis was highly seasonal with recruitment just before the onset of the wet season (June to November), primarily in May and June. This is somewhat different from the case in Huizache-Caimanero lagoon of Mexico where immigration of post-larval Penaeus vannamei occurred during the wet season (Paul \& Bowers 1982). However, flood tidal currents are weak or nonexistent in the Joyuda channel during heavy rainfall 
events, and recruitment by $P$. subtilis probably occurs when flood tidal currents are strongest, in the dry season (December to May).

Although the seasonal pattern of abundance was relatively clear in Penaeus subtilis, $P$. notialis demonstrated 2 recruitment periods within the 12 mo of study, one at the end of the wet season (October to December) and another at the beginning of the second wet season (May to June). Furthermore, highest abundance of $P$. notialis was observed 12 mo from lowest abundance, and it is clear that there may be large annual variation in the abundance of the species in Laguna Joyuda. It seems likely that spawning in $P$. notialis occurs all year and that recruitment into the lagoon population may be more heavily influenced by offshore conditions than by conditions inside the nursery area or inlet. Whether or not recruitment of Penaeus spp. is influenced by spawning stock size is subject to debate (Garcia 1983, Penn 1984, Penn \& Caputi 1984) but offshore reproductive stock size could have a major impact on recruitment success, particularly in the island habitat, where populations are not large and where currents could remove larvae from the insular shelf environment. Laguna Joyuda, with its small basin and single inlet, makes it a convenient system for research concerning larval recruitment.

The importance of tropical coastal lagoons for penaeid fisheries has been pointed out (Edwards 1978), but long-term data including estimates of natural mortality, studies on recruitment, and emigration will be required to elucidate the mechanisms regulating stock sizes. Multiple-species use of tropical lagoons and estuaries, and the lack of distinct seasonal patterns in some of the species, provides a complex fisheries problem, but study on narrow island shelves will permit research with geographically confined populations.

Acknowledgements. This research was supported by a grant from the Office of Sea Grant (National Oceanic and Atmospheric Administration) (Grant no. R/A-01-2) and a grant from the National Science Foundation (Grant no. R-II 86-10677). Dennis Corales cheerfully participated in nearly every field collection, while B. A. Buchanan performed the taxonomic analyses for the Penaeus spp. found in the lagoon. L. L. Cruz assisted in sample processing and data reduction. B. A. Buchanan, J. A. Colley, J. R. Garcia, and anonymous reviewers made thoughtful comments on the manuscript. To all of these persons and the granting agencies, I offer my sincere thanks.

\section{LITERATURE CITED}

Barrett, B. B., Gillespie, M. C. (1973). Primary factors which influence commercial shrimp production in coastal Louisiana. Louisiana Wild. Fish. Comm. Tech. Bull. No. 9: $1-28$

Baxter, K. N. (1962). Abundance of postlarval shrimp - one index of future shrimp success. Proc. Gulf. Carib. Fish. Inst., 15th Ann. Sess., Nov. 1962, p. 79-87
Buchanan, B. A., Stoner, A. W. (1988). Distributional patterns of blue crabs (Callinectes spp.) in a tropical estuary. Estuaries (in press)

Carvajal-Zamora, J. R., Peres-Ramirez, M. A., Cintron-Molero, G. (1980). Estudio de la Laguna Joyuda: un ecosistema marino. Report, Dept. de Recursos Naturales, Programma de Zona Costanera de Puerto Rico. Section 306: 1-94

Copeland, B. J., Truitt, M. V (1965). Fauna of the Aransas Pass inlet, Texas. II. penaeid shrimp postlarvae. Tex. J. Sci. 18: $65-74$

Dragovich, A. (1981). Guianas-Brazil shrimp fishery and related U. S. research activity. Mar. Fish. Rev. 43(2): 9-18

Duronslet, M. J., Lyon, J. M., Marullo, F. (1972). Vertical distribution of postlarval brown, Penaeus aztecus, and white, $P$. setifecus, shrimp during immigration through a tidal pass. Trans. Am. Fish. Soc. 101: 748-752

Edwards, R. R. C. (1978). The fishery and fisheries biology of penaeid shrimp on the Pacific coast of Mexico. Oceanogr. mar. Biol. A. Rev. 145-180

Ewald, J. J. (1969). The Venezuelan shrimp industry. FAO Fish. Rep. 57 (Vol. 3): 765-774

Fischer, W. (ed.) (1978). FAO species identification sheets for fishery purposes. Western central Atlantic (Fishery area 31). Vol. VI. Penaeidae. Food and Agriculture Organization of the United Nations, Rome

Folk, R. L. (1966). A review of grain-size parameters. Sedimentology 6: 73-93

Garcia, S. (1983). The stock-recruitment relationship in shrimps: reality or artifacts and misinterpretations? Oceanogr Trop. 18(1): 25-48

Garcia, S., LeReste, L. (1981). Life cycles, dynamics, exploitation and management of coastal penaeid shrimp stock FAO Fish. Tech. Pap. 203: 1-215

Grady, J. R. (1971). The distribution of sediment properties and shrimp catch on two shrimping grounds on the continental shelf of the Gulf of Mexico. Proc. Gulf Caribb. Fish. Inst., 23rd A. Sess., p. 139-148

Gulland, J. A., Rothschild, B. J. (eds.) (1984). Penaeid shrimps - their biology and management. Fishing News Books Ltd., Farnham, Surrey, England

Hoese, H. D. (1960). Juvenile penaeid shrimp on the shallow Gulf of Mexico. Ecology 41: 592-593

Khandker, N. A. (1969). Some aspects of the biology of white shrimp Penaeus schmitti Burkenroad, in Lake Unare, Venezuela. FAO Fish. Rep. 57 (Vol. 2): 505-512

Kutkuhn, J. H. (1966). The role of estuaries in the development and perturbation of commercial shrimp resources. Spec. Publ. Am. Fish. Soc. 3: 16-36

Levine, E. A. (1981). Nutrient cycling by the red mangrove, Rhizophora mangle L., in Joyuda Lagoon on the west coast of Puerto Rico. M.S. thesis, Mayaguez, Puerto Rico

Lindner, M. J. (1971). Shrimp resources of the Caribbean Sea and adjacent regions. FAO Fish. Rep. 71 (Vol. 2): 149-156

Neiva, G. de S. (1969). Observations on the shrimp fisheries of the central and southern coast of Brazil. FAO Fish. Rep. 57 (Vol. 3): 847-858

Nikolic, M., Ruiz de Quevedo, M. E. (1969). Notas biologicopesqueras sobre camaron blanco Penaeus schmitti Burkenroad 1936. FAO Fish. Rep. 57 (Vol. 3): 1107-1117

Odum, W. E., Heald, E. J. (1975). The detritus-based food web of an estuarine mangrove community. In: Cronin, L. E. (ed.) Estuarine research, Vol. I. Academic Press, New York, p. 265-286

Parker, J.C. (1970). Distribution of juvenile brown shrimp (Penaeus aztecus Ives) in Galveston Bay, Texas, as related to certain hydrographic features and salinity. Contr. mar Sci., Univ. Tex. 15: 1-12 
Paul, R. K. G., Bowers, A. B. (1982). The ecology and Penaeus fishery of a coastal lagoon system in west Mexico. Oceanol. Acta, 1982. Proceedings International Symposium on Coastal Lagoons. SCORI/IABO/UNESCO, Bordeaux, France, 8-14 Sept., 1981, p. 383-388

Penn, J. W (1984). The behavior and catchability of some commercially exploited penaeids and their relationship to stock and recruitment. In: Gulland, J. A., Rothschild, B. J. (eds.) Penaeid shrimps - their biology and management. Fishery New Books, Farnham, England, p. 173-186

Penn, J. W., Caputi, N. (1984). Stock recruitment relationships for the tiger prawn, Penaeus esculentus, fishery in Exmouth Gulf, Western Australia, and their implications for management. In: Rothlisberg, P. (ed.) Proc. 2nd National Prawn Seminar (NPS 2), Cleveland, Queensland, Australia, p. 165-173

Perez-Farfante, I. (1970). Caracteristicas diagnosticas de los juveniles de Penaeus aztecus subtilis, $P$. duorarum notialis y $P$. brasiliensis (Crustacea, Decapoda, Penaeidae). Sep. Mem. Soc. Cienc. Natur. La Salle 30(87): 159-180

Qasim, S. Z., Sankaranarayana, V. N. (1972). Organic detritus of a tropical estuary. Mar. Biol. 15: 193-199

Renfro, W. C. (1963). Small beam net for sampling postlarval shrimp. U. S. Fish Wildl. Serv. Circ. 161:86-87

Rulifson, R. A. (1981). Substrate preference of juvenile penaeid shrimps in estuarine habitats. Contr. mar. Sci. Univ. Tex. 24: 35-52

Sokal, R. R., Rohlf, F. J. (1969). Biometry. W. H. Freeman, San Francisco

Staples, D. J. (1980). Ecology of juvenile and adolescent banana prawn, Penaeus merguiensis, in a mangrove estuary and adjacent offshore area of the Gulf of Carpentaria. I. Immigration and settlement of postlarvae. Aust. J. mar. Freshwat. Res. 31: 635-652
Stoner, A. W. (1985). Macrobenthic consumers in Joyuda Lagoon: residence and transients. In: Stoner, A. W., Lopez, J.M. (eds.) Cycling and transport processes in a tropical lagoon. Proceedings of a workshop on the Joyuda Lagoon ecosystem. Report of the Center for Energy and Environment Research, Univ. Puerto Rico, Mayaguez, p. $34-45$

Stoner, A. W., Lopez, J. M. (1985). Cycling and transport processes in a tropical estuarine lagoon. Proceedings of a workshop on the Joyuda Lagoon ecosystem. Report of the Center for Energy and Environment Research, Univ. Puerto Rico, Mayaguez, p. 1-86

Stoner, A. W. (1986). Community structure of the demersal fish species of Laguna Joyuda, Puerto Rico. Estuaries 9: $142-152$

Tabb, D. C., Dubrow, D. L., Jones, A. E. (1962). Studies on the biology of the pink shrimp, Pendeus duorarum Burkenroad, in Everglades National Park, Florida. Fla. St. Bd Conserv., Mar. Lab., Univ. Miami, Tech. Ser. 37: 1-32

Wells, F. E. (1984). Comparative distribution of macromolluscs and macrocrustaceans in a north-western Australian mangrove system. Aust. J. mar. Freshwat. Res. 35: 591-596

Williams, A. B. (1955). Contribution to the life history of commercial shrimps (Penaeidae) in North Carolina. Bull. mar Sci. Gulf Caribb. 5: 116-146

Young, P. C., Carpenter, S. M. (1977). Recruitment of postlarval penaeid prawns to nursery areas in Moreton Bay, Queensland. Aust. J. mar. Freshwat. Res. 28: 745-774

Zimmerman, R. J., Minello, T J., Zamora, G., Jr (1984). Selection of vegetated habitat by brown shrimp, Penaeus aztecus, in a Galveston Bay salt marsh. Fish. Bull. U. S. 82: $325-334$ 